\title{
Procjena utjecaja pandemije bolesti COVID-19 na komunikaciju manifestacija u hrvatskom turizmu
}

\author{
Dejan Gluvačević* \\ Zvonimir Grgas**
}

\section{SAŽETAK}

Na primjeru velikih kriza pokazuje se kompleksnost suvremenog svijeta. Umreženost koju nam je donijela globalizacija prijeti svaki lokalni problem učiniti globalnim, ali nam je i otvorila mogućnost za udruživanjem ukupnih potencijala čovječanstva u rješavanju zajedničkih problema. Iako pojava pandemije bolesti COVID-19 primarno mobilizira na djelovanje kojim će se zaštiti životi i zdravlje ljudi, nastala kriza snažno je utjecala na sve segmente društava te je pred njih postavila izazove na koje je potrebno odgovoriti. Društveni i gospodarski život znatno se usporio, a komunikacija među ljudima velikim se dijelom preselila $u$ digitalno okruženje. Javnozdravstveni zahtjev za ograničenom mobilnošću ljudi i uvođenje fizičke distance posebno su pogodili turistički sektor koji je do pojave pandemije snažno rastao na krilima globalizacije. Turistički djelatnici imaju sužen prostor djelovanja za vrijeme krize, ali stečena iskustva mogu poslužiti osnaživanju otpornosti na buduće krize, kao i na razvoj novih modela turističkog poslovanja s posebnim naglaskom na komunikaciju u turizmu.

Cilj je ovog rada ispitati na koji način turističke manifestacije u Hrvatskoj komuniciraju prema potencijalnim posjetiteljima u kontekstu COVID-19 krize. Za potrebe rada, prema kriterijima autora, odabrane su manifestacije na području Hrvatske koje imaju turistički karakter, pri čemu se pazilo na ravnomjernu regionalnu zastupljenost. Kontekstualne razlike između manifestacija ne utječu na dobivene rezultate jer je fokus stavljen na univerzalnu komunikaciju и turizmu.

\footnotetext{
* Dr. sc. Dejan Gluvačević, predavač na Edward Bernays Visokoj školi za komunikacijski menadžment, e-mail: dejan.gluvacevic@bernays.hr.

** Zvonimir Grgas, doktorand na Sveučilištu Josipa Jurja Strossmayera u Osijeku, e-mail: grgas.zvonimir@gmail.com.
} 
Kako bi se došlo do ključnih rezultata provedeni su online anketni upitnici s predstavnicima organizatora manifestacija zaduženim za komunikaciju. Autori rada su anketni upitnik podijelili prema vremenskoj crti u tri dijela. Prvi dio odnosio se na komunikacijska iskustva pri organiziranju manifestacije koja se održala prije pandemije COVID-19. Drugi dio odnosio se na komunikaciju vezanu uz manifestaciju za vrijeme krize. Posljednji dio anketnog upitnika bio je predikcijski, odnosno tražio je od komunikacijskih stručnjaka predviđanje komunikacijskih modela u organiziranju manifestacija u postpandemijskom vremenu. Turizam traži stabilnost, ali krizu je potrebno prihvatiti i kao izazov. Na temelju iskustva potrebno je konstruirati procjene budućih modela djelovanja, a pritom je važna suradnja znanstvenika i praktičara u turizmu.

Ključne riječi: komunikacija u turizmu, turizam, pandemija COVID-19, turističke manifestacije

\section{Uvod}

Pojavom pandemije bolesti COVID-19 mnoge ustaljenje prakse morale su biti napuštene, a djelovanje u novonastalim okolnostima prilagođeno je brizi za živote $\mathrm{i}$ zdravlje ljudi. Cjelokupni društveni život usporio se uslijed javnozdravstvenog zahtjeva za ograničenom mobilnošću ljudi i uvođenjem fizičke distance. Takve novonastale okolnosti posebno su pogodile turistički sektor koji je do pojave pandemije snažno rastao na krilima globalizacije. Organizacija turističkih manifestacija u takvim okolnostima od praktičara u turizmu traži da, osim kreativnog proizvoda kojeg nude kao dio turističke ponude, upravljaju krizom uzrokovanom pandemijom. Praktičari odnosa s javnošću i marketinga koji rade u sektorima kulture i umjetnosti, zabave i slobodnog vremena moraju biti sve bolje upoznati s trendovima i događajima kako bi maksimizirali kreativne mogućnosti za planiranje komunikacija (Beresfort i Fawkes, 2009: 664). Mnogi autori primjećuju da je pojavom novih tehnologija komunikacija u turizmu postala izrazito dvosmjerna, a suvremeni turist postao upućeniji i zahtjevniji (Vrtiprah, 2006; Buhalis i Jun, 2011; Sigala i sur., 2012). Na drugoj strani, od turističkih praktičara zaduženih za komunikaciju traži se da razumiju motive, želje i ponašanje svoje publike (Kotler i Scheff, 1997: 69). Složenost komunikacije u organizaciji manifestacija dodatno se komplicira krizom koju kroz aspekt turizma možemo definirati kao svaku negativnu pojavu koja utječe direktno ili indirektno na poslovanje turističkih subjekata te koja kao takva može kratkoročno ili dugoročno utjecati na imidž određenoga turističkog subjekta u javnosti (Gluvačević i Grgas, 2015: 870). Kriza se može dogoditi bilo kome i bilo kad pa mnogi autori ukazuju na važnost pripreme i djelotvornog upravljanja kod kriznih 
Procjena utjecaja pandemije bolesti COVID-19 na komunikaciju manifestacija...

situacija (Tomić, 2008; Zaremba, 2010). Djelotvorno upravljanje kriznim situacijama štiti tvrtke i njihovu reputaciju, a katkad može značiti i sam njihov opstanak (Langford, 2009: 432). Turizam generalno, osobito turističke manifestacije, podrazumijeva slobodu kretanja i interakciju među ljudima. Stoga je pred praktičarima u turizmu izazovan zadatak djelovanja u takvim nepovoljnim okolnostima. Ovaj rad u svom fokusu nema ekonomske i logističke aspekte organiziranja turističkih manifestacija u Hrvatskoj, već se bavi komunikacijom prema potencijalnoj publici prije i za vrijeme COVID-19 krize, a posebno želi istražiti kakva su predviđanja praktičara u turizmu vezanih uz sadržaj i formu komunikacije u vremenu koje će uslijediti nakon završetka krize. Upravo rezultati predikcijskog dijela istraživanja mogu dati doprinos konstruiranju budućih modela komunikacije u turizmu.

\section{Teorijski okvir i pojmovna određenja}

S ekonomskog, ekološkog i turističkog stajališta pozitivni učinci organiziranja događaja na gospodarstvo destinacije, posebice u razdoblju izvan glavne sezone, očituju se u povećanim prihodima i zaposlenosti svih subjekata u turističkoj destinaciji, poboljšanju transporta, komunikacija, infrastrukture, promocije destinacije, zaštite okoliša, a često i u urbanoj transformaciji i obnovi. Turističke manifestacije rastući su fenomen koji brojnim mjestima, nebitno jesu li to veliki gradovi ili manja naselja, omogućava predstavljanje vlastite jedinstvenosti, koje istovremeno doprinose rastućoj koheziji s lokalnom zajednicom. Neophodno je procijeniti vrijednost događaja u stvaranju pozitivnog imidža destinacije, njegovu ulogu u promociji destinacije i stvoriti co-branding događaja i drugih atrakcija u destinaciji (Vrtiprah i Sentić, 2018: 273). Kad govorimo o manifestacijama u turizmu, potrebno je odrediti se prema pojmovima koji često označavaju isti ili sličan sadržaj. Mnoge manifestacije u svom nazivu imaju riječ ,festival“", a postoje razni glazbeni festivali, plesni festivali, filmski festivali, kazališni festivali i mnogi drugi. Pojedini festivali imaju natjecateljski karakter, a neki su isključivo prezentacijski. Rječnik stranih riječi navodi značenje ,festivala“: lat. (festivus - radostan) svetkovina, svečanost; periodička kulturna priredba (muzička, kazališna, kinematografska i sl.) u velikom stilu; smotra umjetnosti (Klaić, 1990: 422). Pojam ,smotra“ najčešće se pojavljuje kao dio pojašnjenja pojma „festival“, a također se u nazivima manifestacija mogu naći pojmovi „dani“, ,,igre“ i slični nazivi. Posebno se preciznom u svojoj fleksibilnosti čini definicija koju su ponudile Petra Kelemen i Nevena Škrbić Alempijević: „Festivali su javna događanja koja imaju vremenski, prostorni i programski okvir. Javnost festivala upućuje da su oni u svojoj srži predstavljački i da svojim zamišljenim okvirom žele uputiti određenu poruku. Nadalje, u njihovo je organiziranje upisana svrha proslave, slavlja određenog elementa kulture. U festivale se uključuju tri tek donekle odijeljene skupine aktera: organizatori, izvođači i publika. Unutar festi- 
valskog okvira smješteni su motivi, svrhe i izvedbe svih uključenih sudionika. Akteri festivala omogućuju da se on dogodi te se unutar zamišljenog prostorno-vremenskog okvira putem njihovih praksi festivali izvode. Okvir festivala pritom nije nepropustan; mnogostruke festivalske izvedbe mogu iskoračiti izvan zamišljenih okvira. Isto tako, festival je svojom povezanošću s društvenim kontekstom jedna od mogućih artikulacija kulturnog života, dok se njegove poruke prelijevaju izvan njegove vremenske i prostorne zadanosti“" (2012: 47).

Iako mnoge manifestacije imaju predturističku povijest i važne su za društvenu identifikaciju neke sredine, ovaj rad manifestacije promatra u kontekstu turističke ponude. Primjetan je trend povezivanja manifestacija i turizma pa tako Cudny (2013: 106) primjećuje da se u zemljama srednje i istočne Europe festivali vidljivo razvijaju i raste značaj festivalskog turizma. Prepoznajući važnost manifestacija za razvoj turizma Getz (2008: 403) ističe da su događanja (events) važni pokretači turizma te naglašava potrebu profesionalizacije kod upravljanja manifestacijama. Zbog sve većeg značaja manifestacija u turističkom poslovanju, za očekivati je daljnju profesionalizaciju kod kreiranja takvih sadržaja, a što znači da obrazovni sektor mora moći producirati usko specijalizirane kadrove koji će biti u stanju zadovoljiti interese brzorastuće turističke industrij: „Bit će teško promijeniti ovaj dobro poznati obrazac profesionalizacije, koji se odnosi na pojedine vrste događanja (kao što je "menadžer festivala", "dizajner izložbe" ili "kreator konvencije"), u opće zanimanje "organizatora događanja"“ (Getz, 2008: 405). Prepoznavanje važnosti manifestacija u turističke svrhe u skladu je s intencijom za ostvarivanje prepoznatljivosti. Naime, cilj je učiniti destinaciju bitnom u globaliziranom svijetu u kojem fizičke granice gube na značenju (Aronczyk, 2013: 3).

Kako se istraživanje odnosi na tri perioda (pretpandemijski, pandemijski i postpandemijski), važno je napomenuti da se prva dva perioda ne podudaraju nužno s kalendarskim godinama. Naime, iako je za većinu turističkih manifestacija pandemijska godina 2020., kod nekih je to 2021. godina jer su prije nastanka krize u 2020. godini održali predviđena događanja (Riječki karneval, Samoborski fašnik). Pod pojmom postpandemije autori ovog rada smatraju period u budućnosti koji će nastupiti u trenutku okončanja krize, a koji je trenutno nemoguće vremenski odrediti.

\section{Metodologija}

Kako bi se uspješno provelo istraživanje pod nazivom Procjena utjecaja pandemije bolesti COVID-19 na komunikaciju manifestacija u hrvatskom turizmu bilo je potrebno koristiti se odgovarajućim istraživačkim metodama kako bi rezultati istraživanja bili ne samo reprezentativni već i relevantni, pružajući uvid u stanje vezano uz ovu problematiku. Provodeći istraživanje, autori su se vodili aktualnom situaci- 
Procjena utjecaja pandemije bolesti COVID-19 na komunikaciju manifestacija...

jom proizašlom iz pandemije COVID-19 u smislu da su tragali za odgovorima koji bi pokazali kakve su bile prakse komuniciranja turističkih manifestacija u Hrvatskoj prije i tijekom pandemije, kao i u kolikoj mjeri te na koji bi način pandemija mogla utjecati na buduću praksu komunikacije turističkih manifestacija u Hrvatskoj. Također, autori postavljaju jednu glavnu i tri pomoćne hipoteze koje prema svojim obilježjima pripadaju kvalitativnim hipotezama (Zelenika, 2000: 420):

- Glavna hipoteza: Iskustvo komunikacijskog menadžmenta manifestacija tijekom pandemije bolesti COVID-19 u manjoj će mjeri utjecati na buduću praksu u komunikaciji manifestacija.

- Pomoćna hipoteza 1: U razdoblju nakon pandemije COVID-19 nastavit će se dominacija online komunikacije manifestacija u odnosu na offline komunikaciju.

- Pomoćna hipoteza 2: U razdoblju nakon pandemije COVID-19 neće biti značajnijih promjena u komunikacijskim aktivnostima vezanih uz vrijeme pripreme manifestacije i broja ljudi uključenih u komunikacijske aktivnosti manifestacija u odnosu na razdoblje organizacije manifestacija prije pandemije.

- Pomoćna hipoteza 3: U razdoblju nakon pandemije COVID-19 sigurnost posjetitelja bit će jedan od pojmova koji će se nalaziti u središtu fokusa komunikacije.

S obzirom na promjenjivu epidemiološku situaciju te mjere koje su bile na snazi, procijenjeno je kako će metoda anketiranja biti dostatna metoda kako bi se dali odgovori na postavljeno istraživačko pitanje. Postoji više vrsta anketiranja tako da bi anketna metoda korištena u ovom istraživanju bila metoda ispitivanja uz pomoć anketnog upitnika koja se provodila online. Prednosti takvog provođenja istraživanja su sljedeće (Zelenika, 2000: 368):

- moguće saznati podatke i informacije o doživljaju;

- mogu se dobiti podaci i informacije o prošlosti, sadašnjosti i budućnosti;

- uglavnom je ekonomična.

Ipak, autori su prilikom pripreme znanstvenog istraživanja i odabira metode koju će koristiti također bili svjesni poteškoća koje su vezane uz metodu anketiranja nastojeći provesti istraživanje tako da postavljena pitanja budu prilagođena da neutraliziraju sve moguće poteškoće koje bi se mogle javiti, a Zelenika (2000: 368) napomijne kako su najčešće upravo epistemološke, psihološke i društvene poteškoće.

Kako bi se neutralizirale navedene poteškoće, autori su kombinirali otvorena i zatvorena pitanja u anketnom upitniku. Anketni upitnik sastojao se od ukupno 15 pitanja i šest (6) potpitanja, od kojih je 11 pitanja bilo zatvorenog tipa, a 10 pitanja otvorenog tipa. Pitanja zatvorenog tipa bila su postavljena odgovorima prema Likertovoj skali. Anketni upitnik provodio se online putem obrasca Google Forms u razdoblju od 5. veljače do 5. ožujka 2021. godine. 
Uzorak ovog istraživanja predstavljaju osobe koje su bile nadležne za komunikacijske aktivnosti različitih turističkih manifestacija u Hrvatskoj. Prilikom određivanja koje manifestacije će biti uključene u istraživanje, autori su prema kriterijima većeg broja posjetitelja i medijske prepoznatljivosti odabrali sljedećih 20 manifestacija iz kontinentalne i primorske Hrvatske koje predstavljaju uzorak:

- Riječki karneval

- Sinjska alka

- Rabska fjera

- Renesansni festival Koprivnica

- Dubrovačke ljetne igre

- Međunarodni dječji festival u Šibeniku

- Samoborski fašnik

- Dani piva Karlovac

- Advent Zagreb

- Đakovački vezovi
- Wings for Life Zadar

- Pula Film Festival

- Dani Jelačića u Zaprešiću

- Splitsko ljeto

- Špancirfest

- Vinkovačke jeseni

- Porcijunkulovo

- Motovun Film Festival

- Picokijada u Đurđevcu

- INmusic Festival Zagreb

Od navedenih 20 manifestacija, njih 17 se odazvalo te je sudjelovalo u istraživanju dok su izostali odgovori Motovun Film Festivala, Picokijade u Đurđevcu i INmusic Festivala u Zagrebu. Kako su autori više puta pokušali doći do organizatora navedene tri manifestacije, ali bez uspješne uspostave veze, to također može biti protumačeno u kontekstu pandemije koja je u tom trenutku još uvijek bila u tijeku i pod snažnijim epidemiološkim mjerama pa su tako izostale komunikacijske aktivnosti organizatora ne samo prema autorima istraživanja nego je primijećen izostanak komunikacije navedenih organizatora na društvenim mrežama, što ukazuje da trenutačno kod navedenih subjekata iz uzorka izostaje bilo kakav vid komunikacije.

\section{Opis manifestacija obuhvaćenih istraživanjem}

Riječki karneval: manifestacija se održava u Rijeci, a izrasla je iz stare narodne karnevalske tradicije s povorkama i plesom. Godine 1982. pod okriljem turističke institucije lokalne zajednice karneval dobiva formalni status iz kojeg je izrastao u najvažniju karnevalsku svečanost u Republici Hrvatskoj.

Sinjska alka: manifestacija se održava u Sinju, a uz kulturni značaj ima i natjecateljski karakter. Radi se o viteškoj igri s višestoljetnom tradicijom koja se održava po strogim pravilima, a sudionici publici predstavljaju svoje vještine u povijesnim odorama te s povijesnom opremom i oružjem. Simbol ove manifestacije je Alkar, jahač na konju. 
Procjena utjecaja pandemije bolesti COVID-19 na komunikaciju manifestacija...

Rabska fjera: manifestacija se održava u Rabu gdje se turistima predstavlja bogata prošlost tog kraja. Radi se o spoju kostimiranih predstava, prezentaciji starih zanata i viteške igre kojim se prikazuje život srednjovjekovnog grada.

Renesansni festival Koprivnica: manifestacija se održava u Koprivnici, a radi se o produkcijski ambicioznom spektaklu koji turistima želi što vjernije dočarati srednjovjekovni život tog kraja.

Dubrovačke ljetne igre: manifestacija koja se održava u Dubrovniku, a utemeljena je 1950. godine. Jedan je od najprestižnijih ljetnih festivala u Republici Hrvatskoj na kojem se održavaju glazbene, dramske i plesne priredbe te izložbe i popratni program.

Međunarodni dječji festival u Šibeniku: manifestacija se održava u Šibeniku, a prvi put je održana 1958. godine. Radi se o festivalu koji ima međunarodni značaj, a na njemu se potiče dječje dramsko, lutkarsko, glazbeno-scensko, filmsko, literarno i likovno stvaralaštvo.

Samoborski fašnik: manifestacija se održava u Samoboru gdje je najveća turistička manifestacija tog kraja. Radi se o spoju starih karnevalskih običaja koji uz bogatu gastronomiju privlače mnoštvo posjetitelja.

Dani piva Karlovac: manifestacija se održava u Karlovcu, a radi se o festivalu piva koje prati bogati gastronomski i koncertni program.

Advent Zagreb: manifestacija se održava u Zagrebu na više lokacija s bogatim kulturno-zabavnim programom uz održavanje Božićnog sajma.

Đakovački vezovi: manifestacija se održava u Đakovu, a utemeljena je 1967. godine. Na festivalu se predstavljaju tradicionalne narodne nošnje te izvode narodne pjesme, plesovi i običaji te mimohod konja.

Wings for Life Zadar: manifestacija se održava u Zadru i ima humanitarni karakter. Dio je globalnog spektakla, a tisuće profesionalaca i amatera trče za one koji zbog zdravstvenih razloga to ne mogu.

Pula Film Festival: manifestacija se održava u Puli, a utemeljena je 1954. godine. Najvažniji je filmski festival u Republici Hrvatskoj. Jedan je od najstarijih nacionalnih festivala na svijetu i festival s najvećim prosječnim brojem gledatelja po filmu, što je zasluga velikog gledališta u Areni.

Dani Jelačića u Zaprešiću: manifestacija se održava u Zaprešiću, a kroz lik bana Jelačića posjetiteljima se približava život 19. stoljeća.

Splitsko ljeto: manifestacija se održava u Splitu, a utemeljena je 1954. godine. Jedan je od najprestižnijih ljetnih festivala u Republici Hrvatskoj koji obuhvaća dramski, operni, baletni i koncertni program.

Špancirfest: manifestacija se održava u Varaždinu i jedan je od najpoznatijih glazbenih i uličnih festivala u Hrvatskoj. 
Medij. istraž. (god. 27, br. 2) 2021. (83-101)

Vinkovačke jeseni: manifestacija se održava u Vinkovcima, a osnovana je 1966. godine. Radi se o tradicionalnome folklornom festivalu i jedan je od najvažnijih folklornih događaja u Republici Hrvatskoj.

Porcijunkulovo: manifestacija se održava u Čakovcu, a bazira se na predstavljanju tradicijskih proizvoda uz bogat umjetničko-zabavni program.

Motovun Film Festival: manifestacija se održava u Motovunu, a utemeljena je 1999. godine. Radi se o filmskom festivalu posvećenom malim i nezavisnim produkcijama diljem svijeta.

Picokijada u Đurđevcu: manifestacija se održava u Đurđevcu od 1968. godine. Radi se o prezentaciji narodne kulture, a središnja priredba je scensko uprizorenje Legende o picokima.

INmusic Festival Zagreb: manifestacija se održava u Zagrebu od 2006. godine i najveći je glazbeni festival na otvorenom u Republici Hrvatskoj.

\section{Rezultati istraživanja}

Glavna hipoteza koja propituje iskustvo komunikacijskog menadžmenta manifestacija tijekom pandemije COVID-19 i buduće prakse komunikacije manifestacija nakon pandemije pokazuju da neće biti značajnijih promjena u budućim praksama nakon pandemije. Naime, dok jedna polovica ispitanika ili ne zna odgovor na postavljeno pitanje ili ne očekuje značajne promjene u komunikaciji prije i poslije pandemije, istovremeno druga polovica ispitanika očekuje da će doći do neznatnijih promjena. Pri tome svaki četvrti ispitanik smatra da će uglavnom doći do promjena, a isti broj njih smatra da uglavnom neće. U jednakoj je mjeri bila zastupljena misao da uglavnom hoće ili uglavnom neće u manjoj mjeri utjecati na buduću praksu u komunikaciji manifestacija. Po jedan ispitanik smatrao je da se u potpunosti ništa neće mijenjati, odnosno da ne zna kakve će promjene nastupiti u budućnosti. Također, kako bi se pojasnili odgovori na dobiveno pitanje, ispitanici su se uglavnom izjašnjavali na načinda će komunikacija biti slična kao prije, odnosno da će i dalje biti zastupljenija online komunikacija, ali isto tako da će se sigurnost nastaviti i dalje komunicirati kao ključan pojam pri komunikacijskom menadžmentu manifestacija. Time je potvrđena glavna hipoteza, a rezultati su prikazani u Grafikonu 1. i Grafikonu 2.

Jedno od glavnih pitanja ovog istraživanja nastojalo je utvrditi postoji li razlika između ispitanika o korištenju komunikacijskih kanala prema potencijalnim posjetiteljima prije razdoblja pandemije COVID-19. Rezultati su pokazali kako je svih 17 sudionika koristilo istovremeno online i offline komunikacijske kanale, potvrđujući jednu uobičajenu komunikacijsku praksu kad se komuniciraju velike turističke manifestacije. Kao online komunikacijski kanali tu se navode internetske stranice, 
Procjena utjecaja pandemije bolesti COVID-19 na komunikaciju manifestacija...

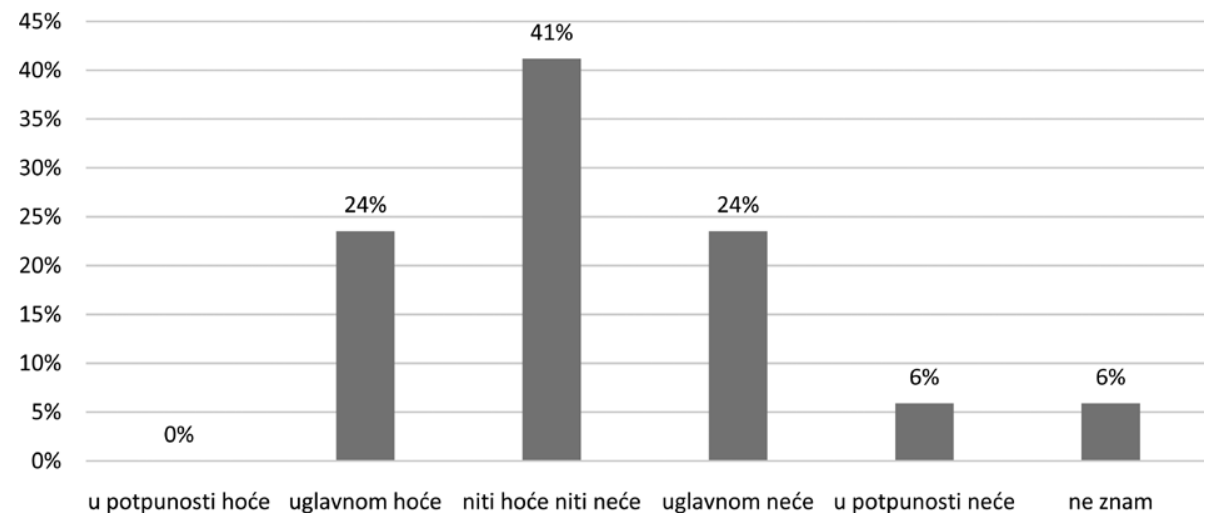

Grafikon 1. Hoće li iskustvo komuniciranja manifestacija tijekom pandemije utjecati na način komuniciranja manifestacija nakon pandemije?

Graph 1. Will the experience of communicating manifestations during a pandemic affect the way events are communicated after a pandemic?

Izvor: autori rada

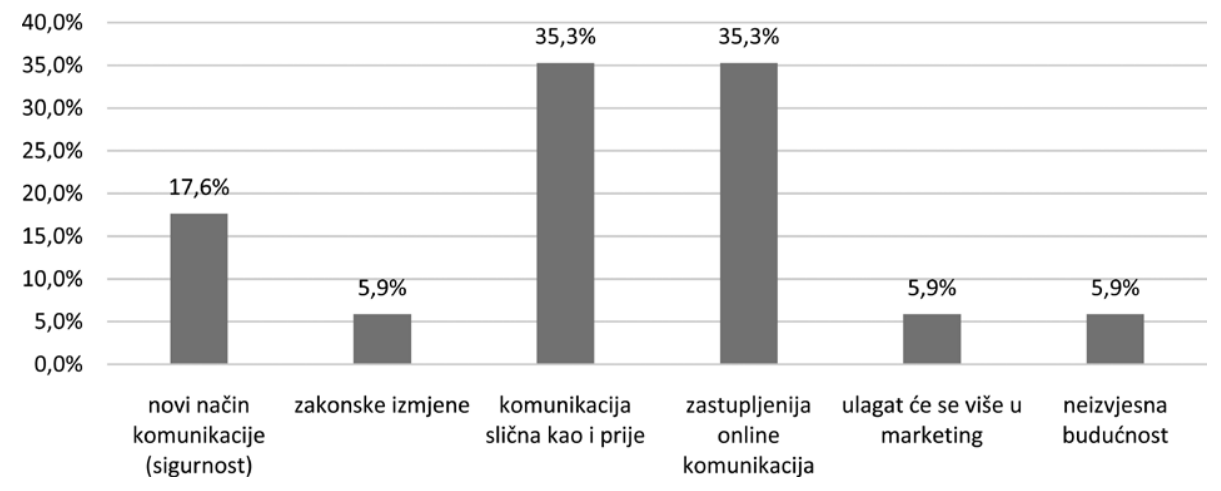

Grafikon 2. Objašnjenje odgovora o utjecaju iskustva komuniciranja manifestacija tijekom pandemije na komunikaciju nakon pandemije

Graph 2. An explanation of the response to the impact of the experience of communicating manifestations during a pandemic on post-pandemic communication

Izvor: autori rada

društvene mreže poput Facebooka i Instagrama, ali i drugih online kanala. S druge strane, kao najčešći offline komunikacijski kanali se ističu brošure, leci, plakati, tiskani oglasi i slično. 
Medij. istraž. (god. 27, br. 2) 2021. (83-101)

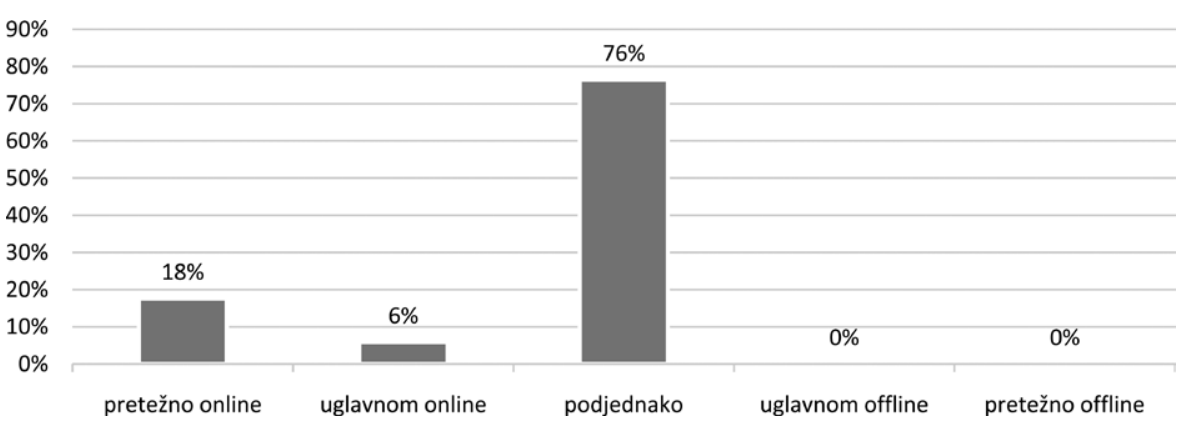

Grafikon 3. Omjer korištenja online i offline komunikacijskih kanala prije pandemije COVID-19

Graph 3. The ratio of the use of online and offline communication channels before the COVID-19 pandemic

Izvor: autori rada

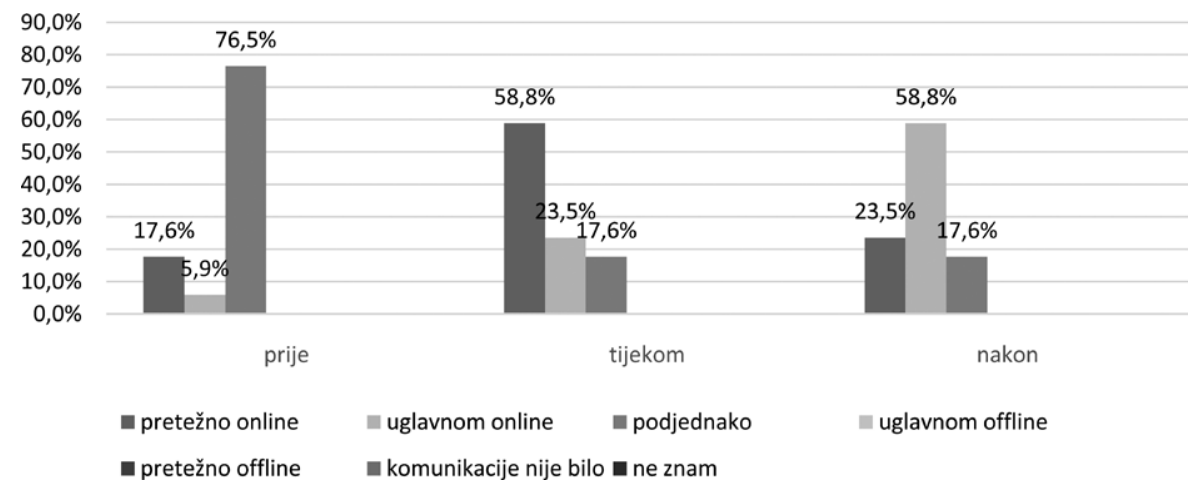

Grafikon 4. Omjer korištenja online i offline komunikacijskih kanala tijekom pandemije COVID-19 i predviđanja nakon pandemije

Graph 4. The ratio of the use of online and offline communication channels during and prediction after the COVID-19 pandemic

Izvor: autori rada

Nastojeći usporediti u kojoj mjeri su online i offline komunikacijski kanali bili zastupljeni prije nastupanja pandemije, također se primjećuje sličan pristup među ispitanicima. Dok se s jedne strane tri četvrtine ispitanika izjasnilo kako su u podjednakoj mjeri koristili online i offline komunikacijske kanale prije pandemije, preostala četvrtina imala je veći fokus na korištenje online komunikacijskih kanala što je vidljivo iz Grafikona 3. 
Procjena utjecaja pandemije bolesti COVID-19 na komunikaciju manifestacija...

Zanimljivo je primijetiti da su se odgovori na isto pitanje mijenjali tijekom pandemije, kao i predviđanja na koji će se način odvijati komunikacija nakon završetka pandemije. U pretpandemijskom razdoblju podjednaka je razina korištenja online i offline komunikacijskih kanala (76,5\%), tijekom pandemije zabilježena je kod nešto manje od petine ispitanika (17,6 \%), dok se primjećuje kako je dominacija online komunikacije zabilježena s ukupnih 82,3 \%. Rezultati istraživanja također pokazuju da će se takav trend zadržati i nakon što pandemija završi s jednom bitnijom razlikom, a to je da online komunikacija neće imati pretežnu dominaciju, ali će i dalje biti dominantan komunikacijski kanal. Prema tim rezultatima istraživanja, a koji su detaljnije prikazani u Grafikonu 4., autori potvrđuju pomoćnu hipotezu 1.

Rezultati pitanja koji su prikazani u Grafikonu 5. i Grafikonu 6. pokazuju trajanje komunikacijskih aktivnosti (Grafikon 5.) te broj uključenih osoba u komunikacijske aktivnosti manifestacija (Grafikon 6.) sa svrhom da se ispita valjanost pomoćne hipoteze 2 .

Na pitanje koje je pokušalo ustanoviti koliko dugo su organizatori promotivno komunicirali manifestaciju prije pandemije, može se primijetiti da je polovica ispitanika komunikacijsku aktivnost provodila unutar tri mjeseca od organizacije manifestacije, dok su nešto duže komunikacijske aktivnosti bile zabilježene kod druge polovice ispitanika, $\mathrm{i}$ to $\mathrm{u}$ podjednakom omjeru komunicirajući manifestacije $\mathrm{u}$ trajanju od tri do šest ili više od šest mjeseci.

Zbog neizvjesnosti koje je nosila pandemija i odgovarajuće epidemiološke mjere, primjećuje se kako se vremensko trajanje komunikacijskih aktivnosti organizacije smanjilo tijekom pandemije na trajanje aktivnosti između jednog i tri mjeseca, što

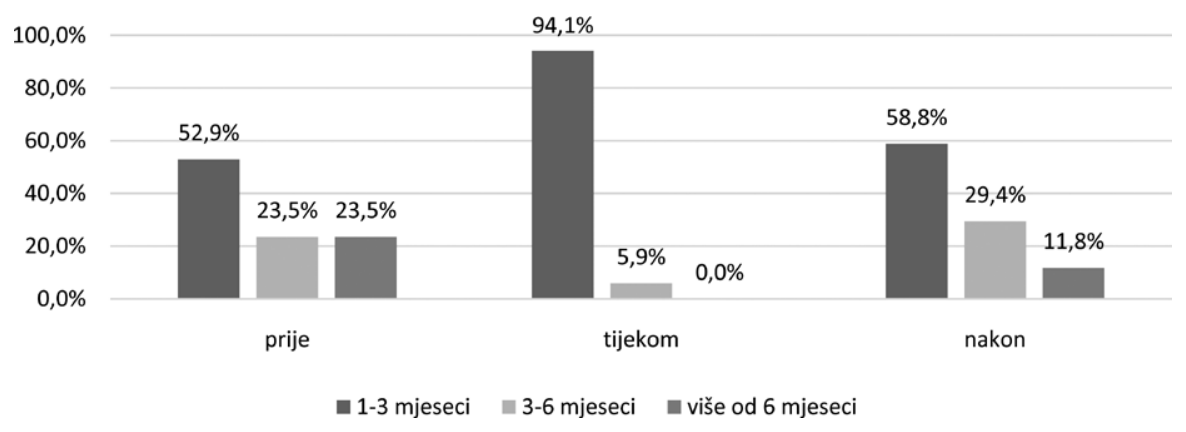

Grafikon 5. Vremensko trajanje promotivne komunikacije prije, tijekom i nakon pandemije COVID-19

Graph 5. Duration of promotional communication before, during and after the COVID-19 pandemic

Izvor: autori rada 
je potvrdilo 16 od 17 ispitanika. U kontekstu njihovih predviđanja, skoro dvije trećine smatra kako će se i nakon pandemije zadržati praksa provođenja komunikacijskih aktivnosti u trajanju do tri mjeseca, a svega dvoje ispitanika smatra da će komunikacijske aktivnosti trajati više od pola godine. Rezultate istraživanja o trajanju promotivnih komunikacijskih aktivnosti manifestacije prije, tijekom i nakon pandemije vidi u Grafikonu 3.

Osim trajanja promotivne komunikacije $\mathrm{u}$ analiziranim razdobljima, autore je zanimalo postoji li promjena u praksi koliko je ljudi sudjelovalo u promotivnoj komunikaciji manifestacije. Istraživanje pokazuje kako je riječ uglavnom o manifestacijama čiju su promotivnu komunikaciju provodile 2 do 3 osobe $(41,2 \%)$ i 4 do 5 osoba $(35,3 \%)$, kao i da se takva praksa neće značajnije mijenjati u razdoblju nakon završetka pandemije. Ipak, očigledna promjena nastupila je tijekom pandemije kad je zabilježeno smanjenje broja osoba koje su sudjelovale u promotivnoj komunikaciji pa je tako i dalje najzastupljenija kategorija s 2 do 3 osobe, ali ovaj put sa značajnijom razlikom u odnosu na druge kategorije. Također, primjetan je i značajniji porast u kategoriji jedne osobe koja je promotivno komunicirala manifestaciju sa skokom od 5,9\% prije pandemije na $23,5 \%$ tijekom pandemije.

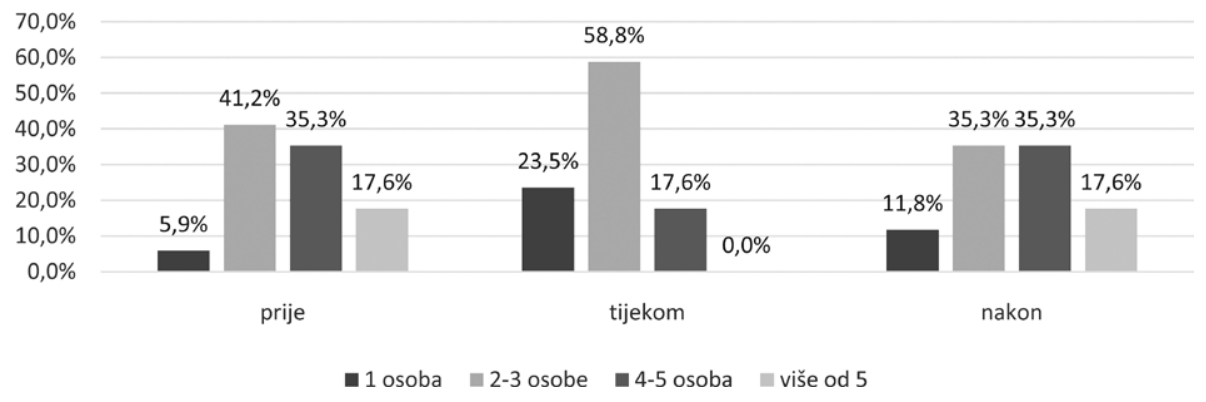

Grafikon 6. Broj uključenih osoba u promotivnoj komunikaciji manifestacije prije, tijekom i nakon COVID-19 pandemije

Graph 6. Number of persons involved in the promotional communication of the event before, during and after the COVID-19 pandemic

Izvor: autori rada

Grafikon 5. i Grafikon 6. jasno pokazuju kako neće biti značajnijih promjena u trajanju komunikacijskih aktivnosti manifestacija i broja uključenih osoba u razdobljima prije i nakon pandemije COVID-19, što potvrđuje tvrdnju postavljenu u pomoćnoj hipotezi 2.

Rezultati prikazani u Grafikonu 1. mogu poslužiti za ispitivanje valjanosti pomoćne hipoteze 3. Naime, na pitanje ispitanicima o predviđanju trendova u komunikacij- 
Procjena utjecaja pandemije bolesti COVID-19 na komunikaciju manifestacija...

skim aktivnostima, pokazalo se da trećina ispitanika smatra da će komunikacija ostati ista kao i ranije, odnosno da će prevladavati online komunikacija. Ako pridodamo jednu trećinu ispitanika koji smatraju da će dominacija online komunikacije biti još izraženija, onda kao treća najzastupljenija kategorija jest i sigurnost kao ključni pojam u komunikaciji koja trenutačno slijedi, ali i koja će se nastaviti i po završetku pandemije. Takvog je mišljenja bila petina ispitanika što se u konačnici može smatrati zadovoljavajućom razinom da se potvrdi i pomoćna hipoteza 3.

Kako bi se dobio uvid u značaj i veličinu analiziranih manifestacija, kao i uvid u utjecaj pandemije COVID-19 te posljedice proizašlih iz epidemioloških mjera, može se jasno primijetiti da je došlo do značajno manjeg broja posjetitelja, ali i u nekim slučajevima drugačijeg pristupa organizaciji manifestacije. Karnevali, kao što su onaj u Rijeci i Samoboru te Špancirfest, tijekom pandemije su, umjesto klasične organizacije manifestacije, bili primorani za virtualnu organizaciju karnevala, fokusirajući se isključivo na online komunikacijske kanale. Također, pojedine manifestacije kao što su ,Renesansni festival Koprivnica, Dani piva Karlovac, Đakovački vezovi te Wings for life nisu bili održani zbog epidemioloških mjera, odnosno jedna četvrtina manifestacija obuhvaćenih istraživanjem. Preostale manifestacije iz istih su razloga zabilježile znatno manji broj posjetitelja zbog pridržavanja mjera održavanja distance, ali i preporuke da se manifestacije komuniciraju ,potiho“ na

Tablica 1. Broj posjetitelja manifestacija prije i tijekom pandemije COVID-19

Table 1. Number of event visitors before and during the COVID-19 pandemic

\begin{tabular}{|l|l|l|}
\hline Manifestacija & Prije pandemije & Tijekom pandemije \\
\hline RIJEČKI KARNEVAL & 100000 & virtualni karneval \\
\hline Sinjska alka & 20000 & 7000 \\
\hline Rapska fjera & 35000 & 8000 \\
\hline Renesansni festival koprivnica & 50000 & otkazano \\
\hline Dubrovačke ljetne igre & 60000 & 20000 \\
\hline Međunarodni dječji festival Šibenik & 10000 & 5000 \\
\hline Samoborski fašnik & 100000 & virtualni karneval \\
\hline Dani piva karlovac & 50000 & otkazano \\
\hline Advent zagreb & 250000 noćenja & 45000 noćenja \\
\hline Đakovački vezovi & 100000 & otkazano \\
\hline Wings for life & 8000 & otkazano \\
\hline Pula film festival & 45500 & 6200 \\
\hline Dani Jelačića Zaprešić & 10000 & 1000 \\
\hline Splitsko ljeto & 8115 & 4665 \\
\hline Špancirfest & 300000 & virtualno \\
\hline
\end{tabular}

Izvor: autori rada 
Medij. istraž. (god. 27, br. 2) 2021. (83-101)

lokalnoj razini. Više o broju posjetitelja na manifestacijama prije i tijekom pandemije prikazano je u Tablici 1 .

Nadalje, kad se uspoređivala komunikacijska praksa prije i tijekom COVID-19 pandemije, većina ispitanika naznačila je kako se komunikacija uglavnom razlikovala (76\%), dok jedna petina (18\%) smatra da nije bilo razlika u komunikacijskom pristupu, a samo jedna manifestacija nije provodila ikakav vid komunikacije prema potencijalnim posjetiteljima. Riječ je o organizatorima manifestacije Dani piva Karlovac, koji svoje komunikacijske aktivnosti nisu niti započeli zbog epidemioloških mjera te su bili svjesni da se manifestacija neće održati te su zbog toga odlučili biti komunikacijski neaktivni. Zanimljivo je primijetiti, kako su osobe zadužene za komunikacijske aktivnosti manifestacije Wings for Life u Zadru, unatoč tomu što su snažne epidemiološke mjere bile na snazi, odnosno proljetni lockdown, komunicirali svoju manifestaciju želeći tako jačati brend manifestacije bez obzira na to što su bili svjesni da se ona u 2020. godini neće održati.

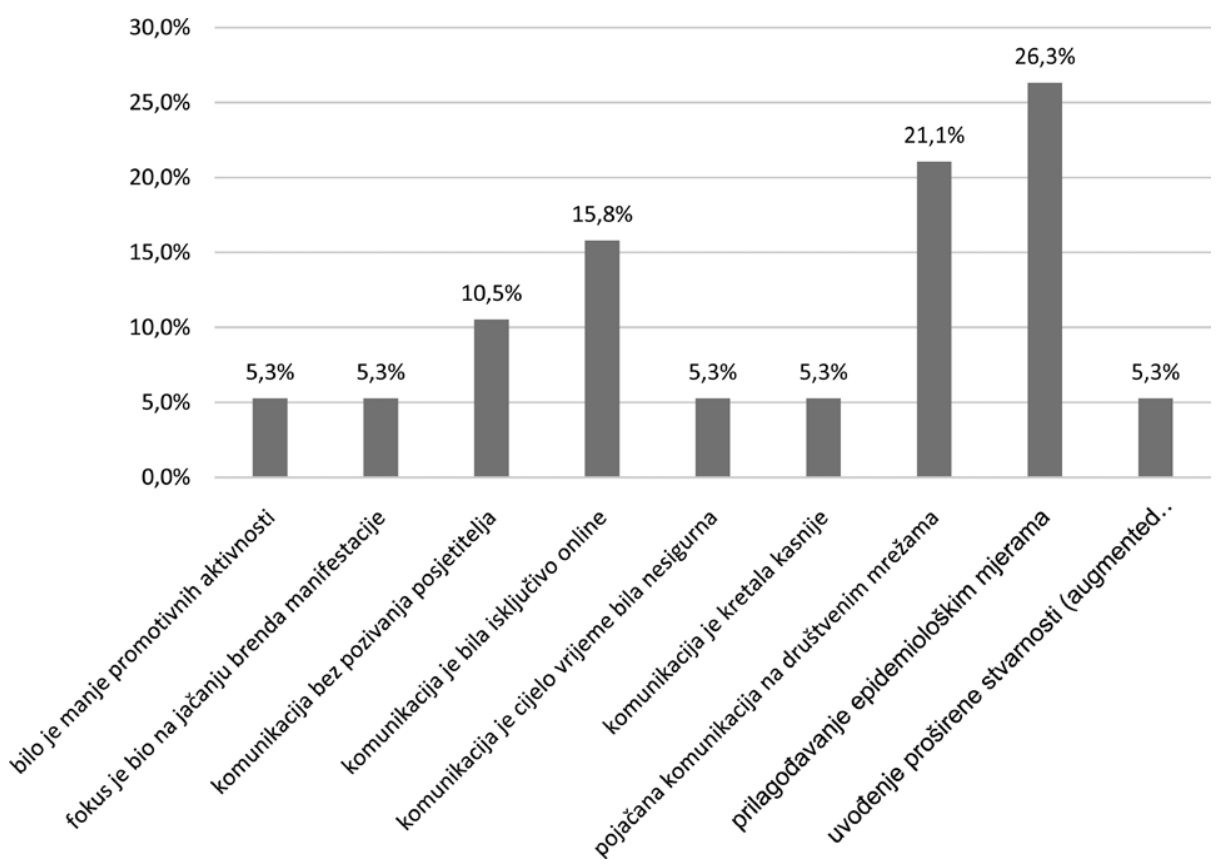

Grafikon 7. Prikaz razloga po čemu se komunikacija razlikovala tijekom pandemije COVID-19 u odnosu na razdoblje prije nastupanja pandemije

Graph 7. Overview of the reasons why communication differed during the COVID-19 pandemic compared to the period before the pandemic

Izvor: autori rada 
Procjena utjecaja pandemije bolesti COVID-19 na komunikaciju manifestacija...

Dubljom analizom razlika u komunikaciji prije i za vrijeme krize vidljiva je dominacija razloga kao što su prilagođavanje epidemiološkim mjerama (26,3 \%), pojačana komunikacija na društvenim mrežama $(21,1 \%)$ te isključivo online komunikacija $(15,8 \%)$, što samo ukazuje na to kako je pandemija preusmjerila organizatore manifestacija u komunikacijskim aktivnostima. Također je zanimljivo primijetiti da je jedna desetina ispitanika (10,5 \%) napisala da zbog epidemioloških mjera na snazi i vezanih preporuka nisu smjeli prema potencijalnim posjetiteljima komunicirati pozivanje na manifestaciju kako bi se spriječilo masovno okupljanje. Više o razlozima po čemu se komunikacija razlikovala tijekom pandemije prikazano je u Grafikonu 7.

Također, kao najčešća pozitivna iskustva u komunikaciji manifestacija tijekom pandemije ispitanici su odgovarali da je komunikacija bila jednostavnija, ekonomičnija, brža, da se povećao broj pratitelja te da je došlo do povećane online interakcije, ali i želja da se posjeti manifestaciju. S druge strane, kao negativna iskustva uglavnom su se isticali smanjeni broj posjetitelja zbog epidemioloških mjera, smanjen program, nesigurni i teški uvjeti rada, nepredvidljivost epidemiološke situacije, nerazumijevanje gostiju zašto je manifestacija otkazana i tome slično.

\section{Zaključak}

Kriza izazvana pandemijom bolesti COVID-19 snažno je utjecala na turistički sektor. Turizam ovisi o stabilnosti, a postojanje interakcije među ljudima uvjet je egzistiranja turističkih manifestacija. Ovim radom autori su istraživali formu i sadržaj komunikacije turističkih manifestacija u Hrvatskoj u kontekstu globalne javnozdravstvene krize i zahtjeva za uvođenjem ograničene mobilnosti i fizičke distance među ljudima. Točnije, propitivali su kako su novonastale okolnosti utjecale na praksu promidžbene komunikacije turističkih manifestacija u Hrvatskoj tijekom pandemije, ali i mogućnosti pojave novih trendova i praksi komunikacije nakon što pandemija završi. Služeći se takozvanom lentom vremena, autori su nastojali utvrditi osnovna načela i prakse komunikacijskih aktivnosti turističkih manifestacija u vremenu prije pojave pandemije, tijekom pandemije te predviđanja turističkih praktičara vezanih za komunikacijske aktivnosti nakon završetka pandemije. Kod odabira manifestacija koje predstavljaju uzorak istraživanja kriteriji su bili da se radi o događanju koji uz ostalo ima i turistički karakter, koji pritom ima značajan broj turističkih posjetitelja, kao i širu medijsku prepoznatljivost te da su zastupljene manifestacije iz kontinentalne i primorske Hrvatske. Autori su svjesni da provedeno istraživanje ima svojevrsna ograničenja kao što su unaprijed strukturirana pitanja čiji su odgovori prikupljeni online putem što je onemogućavalo potencijalno postavljanje dodatnih pitanja i traženja dodatnih pojašnjenja. Također, kao ograničenje 
istraživanja može se navesti namjerni uzorak koji autorima ne dopušta generaliziranje prikupljenih rezultata, već samo interpretaciju nad provedenim uzorkom.

Rezultati istraživanja pokazali su da je do došlo do promjene komunikacije u određenoj mjeri, ali ne toliko značajno da bi se moglo ustanoviti da je pandemija izrazito utjecala na komunikacijske aktivnosti organizatora manifestacija. Naime, prije kao i tijekom pandemije online komunikacijski alati imali su određen stupanj dominacije te samo nešto znatnije korištenje online komunikacijskih alata ne dovodi do zaključka da je došlo i do značajnije promjene u smislu korištenja komunikacijskih alata. No, promjena koja je zabilježena i koja bi mogla ostati prisutna i nakon što pandemija prođe jest stavljanje naglaska na sigurnost posjetitelja prilikom organizacije manifestacija. Promjene u komunikaciji koje su zabilježene ovim istraživanjem $\mathrm{u}$ velikoj se mjeri mogu objasniti javnozdravstvenim zahtjevima za prilagođavanjem epidemiološkim mjerama što je rezultiralo smanjenim brojem posjetitelja zbog pridržavanja distance ili otkazivanjem manifestacija. Za očekivati je da će prestankom pandemijske krize nestati i razlozi za drastičnim promjenama u organizaciji turističkih manifestacija, a time i svojevrsnoga kriznog komuniciranja.

Svaka kriza u određenoj mjeri mijenja svijet kakav poznajemo te nam pruža mogućnost da iz nje nešto naučimo. Provedeno istraživanje kojim je ispitana glavna hipoteza i tri pomoćne hipoteze daje nam usporedbu komunikacije prije i za vrijeme krize, a posebno su zanimljivi rezultati predikcijskog dijela istraživanja koji mogu dati doprinos unaprjeđenju komunikacijskih modela u turizmu. Iako nam rezultati ovog istraživanja ukazuju na to da praktičari u turizmu ne predviđaju radikalne promjene u načinima komunikacije kod organizacije turističkih manifestacija u postpandemijsko doba, ipak se može zaključiti da će doći do određenih promjena. Razlozi za takvo stajalište ne proizlaze samo iz straha vezanih uz javnozdravstvenu sigurnost nego i iz određenih pozitivnih iskustava koja su proizašla iz komunikacijskih aktivnosti, a koje su se odvijale tijekom pandemije. 
Procjena utjecaja pandemije bolesti COVID-19 na komunikaciju manifestacija...

\section{LITERATURA}

Aronczyk, M. (2013) Branding the nation: The global business of national identity. Oxford: Oxford University Press.

Beresfort, S. i J. Fawkes (2009) "Odnosi s javnošću u kulturi i umjetnosti, zabavi i slobodnom vremenu”. U: R. Tench, L. Yeomans, L. (ur.): Otkrivanje odnosa s javnošću. Zagreb: Hrvatska udruga za odnose s javnošću.

Buhalis, D. i S. H. Jun (2011) "E-tourism", 1-38. U: C. Cooper: Contemporary tourism reviews. Oxford: Goodfellow Publishers Limited.

Cudny, W. (2013) "Festival Tourism - The concept, key functions and dysfunctions in the context of tourism geography studies", Geographical Journal, 65 (2), $105-118$.

Getz, D. (2008) "Event tourism: Definition, evolution, and research", Tourism Management, 29 (3), 403-428. doi: 10.1016/j.tourman.2007.07.017.

Gluvačević, D. i Z. Grgas (2015) “Izazovi kriznog komuniciranja u turizmu”. Dani kriznog upravljanja, 8 (1), 867-876.

Kelemen, P. i N. Škrbić Alempijević (2012) Grad kakav bi trebao biti. Zagreb: Jesenski i Turk.

Klaić, B. (1990) Rječnik stranih riječi. Zagreb: Nakladni zavod Matice hrvatske.

Kotler, P. i J. Scheff (1997) Standing Room Only: Strategies for marketing the performing arts. Boston, MA: Harvard Business School Press.

Langford, M. (2009) “Upravljanje kriznim odnosima s javnošću”. U: R. Tench, L. Yeomans (ur.): Otkrivanje odnosa s javnošću. Zagreb: Hrvatska udruga za odnose s javnošću.

Sigala, M., Cristou, E. i U. Gretzel (2012) Social Media in Travel, Tourism and Hospitality: Theory, Practice and Cases. Surrey: Ashgate Publishing Ltd.

Tkalac Verčič, A., Sinčić Ćorić, D. i N. Pološki Vokić (2011) Priručnik za metodologiju istraživanja u društvenim djelatnostima. Zagreb: M.E.P.

Tomić, Z. (2008) Odnosi s javnošću - teorija i praksa. Sarajevo: Synopsis.

Vrtiprah, V. (2006) "Kulturni resursi kao činitelji turističke ponude u 21. stoljeću”, Ekonomska misao i praksa, 3 (2), 279-296. doi: https://hrcak.srce.hr/10683.

Vrtiprah, V. i S. Sentić (2018) "Događaji u funkciji boljeg plasmana turističke destinacije, primjer Dubrovnika", Ekonomska misao i praksa, 27 (1), 267-284.

Zaremba, A. (2010) Crisis Communication: Theory and Practice. New York: Routledge.

Zelenika, R. (2000) Metodologija i tehnologija izrade znanstvenog i stručnog rada. Rijeka: Ekonomski fakultet u Rijeci. 


\section{The Impact Assessment of the COVID-19 Pandemic on the Communication of Events in Croatian Tourism}

\section{Dejan Gluvačević Zvonimir Grgas}

\section{SUMMARY}

The example of the great crises shows the complexity of the modern world. The networking brought to us by globalization threatens to make every local problem global, but it has also opened up the possibility for us to unite the total potentials of humanity in solving common problems. Although the outbreak of the COVID-19 pandemic primarily mobilizes action to protect people's lives and health, the crisis has strongly affected all segments of society and posed challenges to them that need to be addressed. Social and economic life has slowed considerably, and communication between people has largely moved into the digital space. The public health demand for limited mobility of people and the introduction of physical distance have particularly affected the tourism sector, which grew strongly on the wings of globalization until the pandemic. Tourism workers have a narrower scope of action during the crisis, but the experience gained can serve to strengthen resilience to future crises, as well as the development of new models of tourism business, with special emphasis on communication in tourism.

The aim of this paper is to examine how tourist events in Croatia communicate to potential visitors in the context of the COVID-19 crisis. For the needs of the work, according to the criteria of the author, events in the area of Croatia that have a tourist character were selected, taking care of the even regional representation. Contextual differences between events do not affect the results obtained because the focus is on universal communication in tourism. In order to achieve key results, online questionnaire was conducted with representatives of event organizers in charge of communication. The authors of the paper divided the questionnaire according to the timeline into three parts. The first part concerned communication experiences in organizing the event that took place before the COVID-19 pandemic. The second part concerned communication re- 
Procjena utjecaja pandemije bolesti COVID-19 na komunikaciju manifestacija...

lated to the manifestation during the crisis. The last part of the questionnaire was predictive, ie it asked communication experts to predict communication models in organizing events in the post-pandemic period. Tourism seeks stability, but the crisis must be accepted as a challenge. Based on experience, it is necessary to construct estimates of future models of action, and the cooperation of scientists and practitioners in tourism is important.

Keywords: communication in tourism, tourism, COVID-19 pandemic, tourist manifestation 